\title{
Mechanisms and genetic diversity for host plant resistance to spotted stem borer, Chilo partellus in sorghum, Sorghum bicolor
}

\author{
B. U. Singh ${ }^{1,2}$, H. C. Sharma ${ }^{1}$ \& K. V. Rao ${ }^{2}$ \\ 1 International Crops Research Institute for the Semi-Arid Tropics, Andhra Pradesh, India \\ 2 Centre for Plant Molecular Biology, Department of Genetics, Osmania University, Hyderabad, Andhra Pradesh, India
}

\begin{abstract}
Keywords
Chilo partellus, components of resistance, genetic variability, heritability, plant resistance, sorghum, stem borer

\section{Correspondence \\ Hari C. Sharma (corresponding author), International Crops Research Institute for the Semi-Arid Tropics, Patancheru 502 324, Andhra Pradesh, India. \\ E-mail: h.sharma@cgiar.org \\ Received: February 14, 2011; accepted: May 17, 2011.}

doi: $10.1111 / j .1439-0418.2011 .01647 . x$

\begin{abstract}
Levels of resistance to spotted stem borer, Chilo partellus, in the germplasm are low to moderate and therefore we evaluated 25 sorghum genotypes for resistance to stem borer to identify lines with diverse mechanisms of resistance to this insect. Leaf glossiness was significantly and negatively associated with low deadheart formation. Dwarf genotypes with fewer nodes showed more deadheart formation. Antixenosis and/or antibiosis for leaf feeding, and reduced deadheart formation, tunnelling, and number of exit holes resulted in lower losses owing to C. partellus damage. Axillary tillers compensated for loss in grain yield owing to borer infestation as a result of deadheart formation, but their synchrony for maturity with the main plant is quite important. Path coefficient analysis revealed that direct effects of stem tunnelling on loss in grain yield were greater than leaf feeding and deadhearts. However, leaf feeding via stem tunnelling showed maximum indirect effects on loss in grain yield. Estimates for broad-sense heritability and genetic advance suggested that it is possible to improve for grain yield under stem borer infestation. Heritability estimates for grain yield were usually higher than for stem borer damage parameters. Multi-trait cluster analysis placed the test genotypes into four and five clusters in rainy and post-rainy seasons, respectively. The genotypes placed in different groups, and showing resistance to leaf feeding, deadheart formation, stem tunnelling, and/or compensation in grain yield can be used for sorghum improvement.
\end{abstract}

Sorghum [Sorghum bicolor (L.) Moench] is one of the most important cereal crops in the semi-arid tropics and subtropics. Sorghum yields on farmers' fields are generally low $(500-800 \mathrm{~kg} / \mathrm{ha})$ under subsistence farming conditions. Sorghum is damaged by over 150 insect species from planting to the final crop harvest, of which several species of stem borers are important pests of this crop worldwide (Harris 1985; Sharma 1993). Amongst them, the spotted stem borer, Chilo partellus (Swinhoe), is the predominant species in the Indian subcontinent, and eastern and southern Africa (Harris 1990; Sithole 1990).
The spotted stem borer, C. partellus, infests the sorghum crop from second week after seedling emergence until harvest and affects all the aboveground plant parts. First- and second-instar larvae feed actively on the tender whorl leaves causing pinholes and elongated lesions. Larval entry at the apical meristem results in drying of 2-3 central leaves, known as a 'deadheart'. Larval feeding on the leaves reduces plant vigour, photosynthetic efficiency and grain filling. The deadheart formation results in loss in plant stand. Third-instar larvae leave the whorl leaves and bore into the 
stem base and cause extensive stem tunnelling, which not only affects the nutrient supply to the developing grain but results in partial or completely chaffy panicles. In addition, stem tunnelling also weakens the stems and may cause lodging and predisposition to infection by stalk rots. Prior to pupation, the full-grown larvae cut exit holes in the stem to enable the emerging moths to escape.

Extent of losses owing to spotted stem borer, C. partellus, in different commercial cultivars and landraces and across the regions have not been quantified (Sithole 1990; Reddy and Walker 1990), probably due to a large variation in cultivars grown. The extent of losses depends not only on larval density and their distribution within the plant, but also on the crop age when the infestation takes place. The grain yield losses owing to stem borers have been estimated to exceed US \$334 million annually (ICRISAT 1992). Insecticide application for stem borer control is uneconomical under subsistence farming and beyond the reach of resource-poor farmers. Considering the ecological and economic impacts, the development and deployment of genotypes with resistance to stem borer as a component of integrated pest management is one of the most appropriate interventions for controlling this pest. There has been little progress in breeding for resistance to this pest, because of the complex interactions between the insect and the host plant. Damage to the plant by the stem borer larvae results in leaf feeding, deadhearts, stem tunnelling and exit holes (Bardner and Fletcher 1974). In addition, the plants have also evolved diverse strategies to withstand stem borer damage and grow under stem borerinduced stress that occurs during different stages of crop growth.

Resistance to stem borer damage is expressed in terms of antixenosis, antibiosis and tolerance, and there are genotypic differences in the expression of different mechanisms of resistance to C.partellus (Jotwani et al. 1978; Singh et al. 1983; Singh and Rana 1984; Taneja and Woodhead 1989; Sharma and Nwanze 1997). Many studies have attempted to partition the contribution of different components of resistance to C.partellus, and resistance is largely controlled by additive gene action (Sharma et al. 2007). However, effects of different damage variables on grain yield loss are not fully understood, and vary across cultivars, seasons, and locations (Singh et al. 1983), variation in onset of borer infestation (Taneja and Nwanze 1989), interplant variation (Harris 1962), and compensation in grain yield
(Heinrich et al. 1983; van den Berg et al. 1990; Sharma and Nwanze 1997; Sharma et al. 2007). To achieve an overall improvement in host plant resistance to stem borer, there is a need to quantify the contribution of different damage parameters towards loss in grain yield. These studies were therefore undertaken to investigate the contribution of different damage parameters towards loss in grain yield, genetic variability for different components of resistance, and the use of various morphological traits as selection criteria to improve the efficiency of screening and selection for resistance to stem borer in sorghum.

\section{Materials and Methods}

\section{Plant material}

Twenty-five grain sorghum genotypes comprising of 15 germplasm accessions with different levels of resistance to C. partellus (IS 1044, IS 1054, IS 2123 , IS 2146, IS 2263, IS 2269, IS 2309, IS 5469, IS 5566, IS 5604, IS 12308. IS 13100, IS 18333, IS 18573 and IS 21444) (Sharma et al. 2003), two local cultivars from Africa (Naga White and Seredo), one midge resistant line (AF 28), one commercial hybrid (CSH 9), one variety (ICSV 112), 3 elite lines (ICSV 705, ICSV 714, and ICSV 743), one resistant (IS 2205) and one susceptible (ICSV 1) checks were evaluated for resistance to spotted stem borer during rainy season, and post-rainy season, at the International Crops Research Institute for the Semi-Arid Tropics (ICRISAT), Patancheru, Andhra Pradesh, India.

\section{Field trials}

All the genotypes were planted in 4-row plots of $2 \mathrm{~m}$ length, with ridges $75 \mathrm{~cm}$ apart, in a randomized complete block design with 3 replications. The plots were fertilized with a basal application of $40 \mathrm{~kg}$ $\mathrm{N}$ and $40 \mathrm{~kg} \mathrm{P}_{2} \mathrm{O}_{5} / \mathrm{ha}$. The seedlings were thinned to a spacing of $10 \mathrm{~cm}$ between the plants by maintaining a final population of 20 seedlings $2 \mathrm{~m} / \mathrm{row}$. All the cultural practices such as inter-cultivation and weeding were carried out to maintain a weed-free crop in both the seasons. Nylon bags (30 mesh) were used to cover the panicles at the flowering stage to prevent damage by birds. In each 4-row plot, two rows were infested with neonates of stem borer at 20 days after seedling emergence, whilst the remaining two rows were left uninfested to serve as an uninfested control. 


\section{Insect rearing and artificial infestation}

The artificial diet developed at ICRISAT, Patancheru, was used for mass rearing of spotted stem borer, $C$. partellus, with the following ingredients (required to prepare 15 jars of $300 \mathrm{~g}$ diet each): (Fraction A: water - $2000 \mathrm{ml}$, kabuli chickpea (Cicer arietinum) flour - $438.4 \mathrm{~g}$, Brewer's yeast - $32 \mathrm{~g}$, sorbic acid $4 \mathrm{~g}$, vitamin $\mathrm{E}$ (Viteolin capsules) - $4.6 \mathrm{~g}$, methyl para hydroxy benzoate - $6.4 \mathrm{~g}$, ascorbic acid $10.4 \mathrm{~g}$, sorghum leaf powder $(\mathrm{CSH} 1)-160 \mathrm{~g}$ and Fraction B: agar-agar - 40.8 g, water - $1600 \mathrm{ml}$, formaldehyde $(40 \%)-3.2 \mathrm{ml}$ ) (Taneja and Leuschner 1985). Freshly emerged larvae were artificially released by a 'Bazooka' applicator into the leaf whorls at 15 days after seedling emergence (Sharma et al. 1992).

\section{Observations}

Data were recorded on leaf feeding at 15 days after artificial infestation on a 1-9 damage rating scale (Guthrie et al. 1960; Dabrowski and Kidiavai 1983; Sharma et al. 1992) ( $1=$ no visible leaf damage or a small number of pin/shot holes on a few leaves and $9=$ most leaves with long lesions). Deadheart counts were taken at 25 days after infestation and expressed in percentages. From the infested plots, five randomly selected plants were cut from the base prior to harvest. Exit holes were counted in each plant after removing the sheath leaves. The plants were then split open to measure the tunnel length/plant $(\mathrm{cm})$, which was represented as percentage tunnelling relative to plant height. Prior to harvest, data were also recorded on overall resistance score based on leaf feeding, deadhearts, plant height reduction, and productive tillers $(1=$ highly resistant and 9 = highly susceptible), and recovery score $(1=\operatorname{good}$ recovery in terms of plant height, productive tillers and panicle size, and $9=$ poor recovery in terms of reduced plant vigour, deadhearts and fewer productive tillers). Data on seedling vigour ( $1=$ high vigour and $5=$ poor vigour) (Maiti et al. 1978) and leaf glossiness $(1=$ glossy and $5=$ non-glossy) were recorded at 15 days after seedling emergence (Maiti et al. 1984; Sharma and Nwanze 1997). Data on $50 \%$ flowering were recorded in both the infested and uninfested rows. Before harvest, the plant height from both the infested and uninfested rows was measured in five randomly selected plants. The per cent reduction in plant height of the infested plants was computed in relation to height of the uninfested plants. Similarly, the number of nodes was counted on each plant in both the infested and uninfested plots, and the differences between them were computed. Number of productive tillers in response to borer infestation was recorded at maturity. Data were also recorded on agronomic score based on plant height, panicle size, panicle exertion and grain yield on a $1-5$ rating scale $(1=$ good grain yield and $5=$ poor grain yield and agronomic desirability).

\section{Statistical analysis}

Data were subjected to analysis of variance, and the significance of differences between the genotypes was tested by F-test, whilst the genotype means were compared with least significant difference (LSD) at $\mathrm{P}=0.05$. Data were subjected to correlation and path coefficient analysis to understand the direct and indirect effects of different morphological traits on stem borer damage, loss in grain yield and genotypic resistance to stem borer. Broad-sense heritability estimates were calculated on an entry mean basis (Hallauer and Miranda 1981). Expected gains from selection (5\% selection pressure) were obtained according to Frey and Horner (1955). The relationship between genotype responses to borer damage and agronomic variables, selection criteria, and grain yield performance was determined by multiple correlations. Phenotypic (PCV) and genotypic (GCV) coefficients of variation were computed following Burton (1951). Multiple correlation coefficients were calculated using the method given by Johnson et al. (1955). Multi-trait clustering between the genotypes was computed using $D^{2}$ analysis of Mahalanobis (1928) and Rao (1952). The $D^{2}$ values between ith and jth genotypes for ' $K$ ' characters were computed as:

$$
D^{2} i j=\sum_{t=1}^{K}\left(Y_{i t}-Y_{j t}\right)^{2}
$$

where $Y_{\text {it }}$ is the uncorrelated mean value of $i$ th genotypes for ' $t$ ' character, $Y_{\mathrm{jt}}$ is the uncorrelated mean value of $j$ th genotype for ' $t$ ' character and $D^{2}{ }_{\mathrm{ij}}$ is the $D^{2}$ between of ith and jth genotype. The ' $K$ ' components of $D^{2}$ for each combination were ranked in descending order of magnitude, and the ranks were added up for each component. Overall $D^{2}$ combinations were used to obtain the rank total. If two populations had smallest distance from each other, a third population with smaller average $D^{2}$ value from the first two populations was added. Then, the nearest fourth one was considered and so on. When there was an abrupt increase in the 
average $D^{2}$ after adding a particular population, then the population was not added in the first cluster. Similarly, a second cluster was formed. This process was continued till all the populations were included into one or the other cluster. The average intra- and inter-cluster distances $\left(D^{2}\right)$ were calculated as:

$$
\text { Averageintra }- \text { cluster distance }\left(D^{2}\right)=\frac{\sum D^{2} i}{n}
$$

where $\Sigma D^{2} i=$ sum of distance between all possible combinations and $n=$ number of genotypes included in a cluster. Its square root represented the distance within cluster (intra-cluster) distance. For calculating the average inter-cluster distances, the average $D^{2}$ value of all possible combinations of genotypes within a cluster with those in another was computed and its square root was used to represent the statistical distance between the two clusters (inter-cluster distance). The mean of a cluster for a particular character was the summation of mean values of lines included in a particular cluster divided by number of lines in that cluster. These values were calculated separately for each character and each cluster.

\section{Results}

Reaction of sorghum genotypes to damage by spotted stem borer, Chilo partellus

There was a significant variation amongst the sorghum genotypes for different types of damage by C. partellus. In general, the extent of damage was greater during the rainy season than in the postrainy season (Table 1). Leaf feeding damage was significantly lower on IS 5566 and IS 2269 [damage rating (DR) < 3.7], followed by IS 1044, IS 2309, IS 5469, IS 5604 and ICSV 714 (DR $<5.30)$ in the rainy season. During the post-rainy season, leaf feeding damage was low on IS 12308 (3.0) and ICSV 714 (3.0), but these were not significantly different from the resistant check, IS 2205 (4.0). Other genotypes with moderate leaf feeding (DR 4.7-5.3) included IS 1054, IS 5469, IS 5566, IS 5604, IS 18573, IS 21444, Naga White, AF 28, CSH 9, IS 2205 and ICSV 1.

The per cent plants with deadhearts were significantly low in IS $1044(34.0 \%)$, followed by IS 18333, IS 2205, IS 2146, IS 5604, IS 18573, IS 2309 and IS 5469 (39.3-47.1\% deadhearts). These genotypes were significantly less susceptible than the susceptible check, ICSV $1 \quad(56.9 \%$ deadhearts $)$. Deadheart formation was significantly lower in IS 12308 , IS 13100 , IS 2146 , IS 18333, IS 5469, IS
2123, IS 18573, IS 1054 and IS $2309(<10.1 \%)$ as compared to Seredo, IS 5604, CSH 9, ICSV 743 and ICSV $1(>28.1 \%)$ during the post-rainy season. In general, the genotypes IS 1044 , IS 2146 , IS 2309 , IS 5469, IS 18333, IS 18573 and IS 2205 showed low deadheart formation in both the seasons. Significantly fewer exit holes/stalk $(<0.73)$ were observed on IS 1054, ICSV 1, CSH 9, IS 2263, AF 28, IS 21444, Seredo, ICSV 714, IS 2146 and IS 2205 during the rainy season. In contrast, the genotypes IS 12308, IS 13100 and IS 2309 had more number of exit holes/stalk. During the post-rainy season, the number of exit holes was greater in IS 2146, IS 2205, ICSV 1, Seredo, IS 2123, IS 2269, IS 18333 and IS 12308 as compared to other genotypes tested. The genotypes IS 1054, IS 21444 and AF 28 had fewer exit holes/plant in both the seasons.

The tunnel length/plant was considerably shorter in IS 2123, IS 21444 and ICSV 714 than in IS 2309, IS 2146, IS 2269, IS 5566, IS 12308, IS 18333 in both the seasons, indicating greater levels of antibiosis to C. partellus in these genotypes. Recovery of larvae and pupae/plant from the harvested stems was significantly higher $(>0.95)$ in ICSV 112, IS 5566, IS 2309, AF 28, ICSV 714, IS 12308, IS 2205, IS 13100 and Naga White as compared to other genotypes tested in the rainy season. The recovery resistance was high in case of IS 5566, ICSV 705, IS 1044, Seredo, IS 2309, IS 2263 and IS 1054 as compared to IS 12308, IS 13100 and AF 28 in both the seasons. The genotypes IS 5566, IS 2123, IS 2146 , IS 5469, IS 5604 and IS 12308 showed an overall resistance score of $<4.3$ in rainy season and were at par with the resistant check, IS 2205. The genotypes IS 5469, IS 2123, IS 13100, ICSV 714 and IS 2205 had a resistance score of $<4.2$ during the post-rainy season as compared to 9.0 of ICSV 1. Moderate levels of resistance were exhibited by IS 5469 and IS 2123 in both the seasons.

Variation in morphological traits associated with resistance to spotted stem borer, Chilo partellus

There were significant differences amongst the sorghum genotypes for the morphological and agronomic traits such as seedling vigour, leaf glossiness, productive tillers, days to $50 \%$ flowering, plant height, number of nodes/plant and grain yield (Table 2). The genotypes IS 12308 and IS 13100 showed poor seedling vigour (score $>3.0$ ), whilst IS 21444 and Naga White showed good seedling vigour $(<2.0)$ in both seasons. The genotypes IS 1054, IS 2123 , IS 2146 , IS 2263 , IS 2269 , IS 2309 , IS 5566 , IS 
Table 1 Expression of resistance to spotted stem borer, Chilo partellus, in 25 genotypes of sorghum during the rainy and post-rainy seasons (ICRISAT, Patancheru, India)

\begin{tabular}{|c|c|c|c|c|c|c|c|c|c|c|c|c|c|c|}
\hline \multirow[b]{2}{*}{ Genotype } & \multicolumn{2}{|c|}{$\begin{array}{l}\text { Leaf feed- } \\
\text { ing score } \\
\text { (LFS) }\end{array}$} & \multicolumn{2}{|c|}{$\begin{array}{l}\text { Deadhearts (\%) } \\
(\mathrm{DH})\end{array}$} & \multicolumn{2}{|c|}{$\begin{array}{l}\text { Exit holes/ } \\
\text { plant (EH) }\end{array}$} & \multicolumn{2}{|c|}{$\begin{array}{l}\text { Stem tunneling } \\
\text { (\%) (TN) }\end{array}$} & \multicolumn{2}{|c|}{$\begin{array}{l}\text { Larvae/pupae/ } \\
\text { plant (LP) }\end{array}$} & \multicolumn{2}{|c|}{$\begin{array}{l}\text { Overall } \\
\text { resistance } \\
\text { (ORS) }\end{array}$} & \multicolumn{2}{|c|}{$\begin{array}{l}\text { Recovery } \\
\text { resistance } \\
\text { (REC) }\end{array}$} \\
\hline & $\mathrm{R}$ & PR & $\mathrm{R}$ & PR & $\mathrm{R}$ & PR & $\mathrm{R}$ & PR & $\mathrm{R}$ & PR & $\mathrm{R}$ & PR & $\mathrm{R}$ & PR \\
\hline IS 1044 & 5.0 & 6.3 & 34.00 & 13.35 & 3.07 & 0.47 & 11.58 & 27.71 & 0.88 & 0.71 & 5.7 & 5.3 & 8.4 & 8.4 \\
\hline IS 1054 & 6.3 & 5.0 & 62.91 & 9.02 & 0.53 & 1.07 & 8.96 & 26.49 & 0.80 & 0.78 & 6.3 & 4.7 & 7.8 & 7.2 \\
\hline IS 2123 & 6.7 & 6.0 & 51.18 & 7.29 & 2.00 & 1.53 & 9.74 & 31.46 & 0.80 & 0.71 & 3.7 & 4.0 & 6.0 & 7.2 \\
\hline IS 2146 & 5.7 & 3.7 & 42.35 & 5.50 & 1.73 & 2.27 & 10.11 & 31.43 & 0.71 & 0.75 & 3.7 & 5.0 & 6.6 & 6.6 \\
\hline IS 2263 & 6.3 & 5.3 & 57.82 & 14.00 & 2.33 & 0.80 & 11.54 & 26.89 & 0.84 & 0.71 & 5.3 & 6.0 & 7.2 & 7.2 \\
\hline IS 2269 & 3.7 & 4.3 & 59.96 & 17.36 & 2.60 & 1.60 & 10.77 & 31.32 & 0.82 & 0.71 & 4.7 & 5.0 & 6.6 & 6.6 \\
\hline IS 2309 & 5.3 & 6.7 & 46.47 & 10.07 & 4.00 & 0.27 & 11.14 & 26.78 & 0.95 & 0.71 & 4.7 & 5.7 & 8.4 & 7.8 \\
\hline IS 5469 & 5.0 & 4.7 & 47.06 & 7.01 & 2.37 & 0.53 & 10.67 & 28.58 & 0.88 & 0.71 & 4.0 & 3.0 & 7.8 & 5.4 \\
\hline IS 5566 & 3.7 & 5.0 & 53.16 & 13.40 & 2.27 & 1.10 & 10.85 & 29.24 & 0.94 & 0.71 & 3.0 & 6.3 & 7.8 & 9.0 \\
\hline IS 5604 & 5.0 & 4.7 & 42.49 & 24.83 & 2.20 & 0.40 & 11.01 & 30.60 & 0.71 & 0.75 & 4.0 & 5.3 & 6.6 & 6.0 \\
\hline IS 12308 & 6.0 & 3.0 & 66.53 & 4.05 & 5.03 & 1.93 & 20.70 & 35.67 & 1.00 & 0.75 & 4.0 & 5.0 & 5.4 & 3.6 \\
\hline IS 13100 & 5.3 & 5.3 & 69.63 & 4.05 & 4.27 & 0.33 & 19.54 & 27.03 & 1.05 & 0.75 & 5.0 & 4.0 & 9.0 & 4.2 \\
\hline IS 18333 & 6.7 & 6.3 & 39.29 & 5.81 & 2.93 & 2.07 & 13.88 & 19.23 & 0.80 & 0.75 & 5.0 & 4.3 & 8.4 & 7.2 \\
\hline IS 18573 & 5.7 & 4.7 & 44.28 & 8.98 & 2.93 & 1.13 & 10.61 & 26.01 & 0.87 & 0.78 & 6.0 & 5.7 & 7.2 & 7.8 \\
\hline IS 21444 & 6.0 & 4.7 & 56.04 & 15.18 & 1.73 & 0.13 & 9.41 & 31.21 & 0.80 & 0.71 & 6.7 & 7.3 & 4.8 & 6.0 \\
\hline Naga White & 5.7 & 4.7 & 70.81 & 14.06 & 3.10 & 0.07 & 20.20 & 27.12 & 1.14 & 0.71 & 6.0 & 6.3 & 7.2 & 6.0 \\
\hline Seredo & 5.7 & 5.7 & 50.72 & 26.02 & 1.60 & 1.60 & 12.89 & 30.23 & 1.04 & 0.86 & 5.7 & 7.0 & 7.8 & 7.8 \\
\hline AF 28 & 6.3 & 4.3 & 62.18 & 15.77 & 1.07 & 0.80 & 11.02 & 22.87 & 0.97 & 0.71 & 5.7 & 5.0 & 5.4 & 4.8 \\
\hline CSH 9 & 6.0 & 4.7 & 63.21 & 21.16 & 1.60 & 1.27 & 16.86 & 30.26 & 0.85 & 0.78 & 8.7 & 4.7 & 8.4 & 5.4 \\
\hline ICSV 112 & 7.7 & 6.7 & 64.56 & 13.81 & 2.13 & 1.07 & 15.65 & 30.94 & 0.93 & 0.75 & 8.7 & 6.7 & 5.4 & 7.8 \\
\hline ICSV 705 & 6.0 & 5.3 & 51.66 & 17.95 & 2.33 & 0.53 & 17.28 & 30.10 & 0.82 & 0.71 & 6.7 & 6.3 & 6.6 & 8.4 \\
\hline ICSV 714 & 4.7 & 3.0 & 59.73 & 16.10 & 1.87 & 0.33 & 12.82 & 29.46 & 0.97 & 0.75 & 8.0 & 3.3 & 7.2 & 5.4 \\
\hline ICSV 743 & 6.7 & 5.7 & 61.81 & 23.13 & 2.93 & 0.80 & 14.41 & 28.74 & 0.75 & 0.75 & 7.3 & 8.0 & 5.4 & 9.0 \\
\hline IS 2205 (R) & 6.0 & 4.0 & 40.58 & 15.84 & 1.93 & 1.20 & 11.38 & 28.14 & 1.01 & 0.75 & 4.3 & 3.7 & 7.2 & 5.4 \\
\hline ICSV 1 (S) & 7.3 & 5.0 & 56.88 & 28.14 & 1.07 & 1.20 & 13.14 & 32.78 & 0.80 & 0.71 & 9.0 & 7.3 & 6.6 & 7.2 \\
\hline Mean & 5.8 & 5.0 & 54.21 & 14.08 & 2.39 & 0.98 & 13.05 & 28.81 & 0.88 & 0.74 & 5.7 & 5.4 & 7.0 & 6.7 \\
\hline LSD at $P 0.05$ & 0.6 & 0.6 & 14.02 & 8.78 & 1.40 & 1.14 & 5.37 & 6.19 & 0.19 & 0.15 & 1.3 & 1.2 & 2.4 & 1.7 \\
\hline
\end{tabular}

PR, Post-rainy season; and R, Rainy season.

5604, IS 18333, IS 18573, ICSV 705, ICSV 714 and IS 2205 were highly glossy, whilst ICSV 743, CSH 9, Seredo, Naga White, ICSV 1 and AF 28 were nonglossy.

The number of productive tillers was significantly higher (1.7) in IS 12308 as compared to IS 18333, IS 2309, IS 18573, IS 2263 and IS 1044 (0.7 tillers/ plant) during the rainy season. The genotypes ICSV 705, IS 2269, IS 1054, IS 2205, IS 12308 and IS 2123 showed good recovery resistance (2.4-3.3 tillers/plant) during the post-rainy season. The genotypes IS 1054, IS 2123, IS 2269, IS 12308, ICSV 705 and IS 2205 had more productive tillers in both the seasons than in ICSV 1. Tillers of infested plants of IS 18573 and AF 28 in the rainy season and AF 28, IS 2146 , IS 2263, IS 2309, IS 5469, IS 5566, IS 5604, IS 18573, ICSV 743 and IS 2205 during the post- rainy season were taller than the main uninfested plants of these genotypes. The genotypes IS 18573 , IS 18333 and IS 2146 were significantly taller than ICSV 705, ICSV 1, CSH 9 and ICSV 714. The genotypes IS 2146, IS 18333 and IS 13100 in rainy season and ICSV 714, IS 18573 and CSH 9 in the post-rainy season exhibited a greater degree of reduction in plant height without a significant reduction in grain yield. In contrast, the genotypes ICSV 1 and IS 5469 in the rainy season and IS 5566, ICSV 743 and IS 2263 in the post-rainy season showed a proportionate reduction in plant height and grain yield owing to borer infestation, suggesting that effects of borer infestation on grain yield were primarily through the adverse effects during the vegetative stage of the crop. In rainy season, the numbers of nodes/plant were maximum in case of 


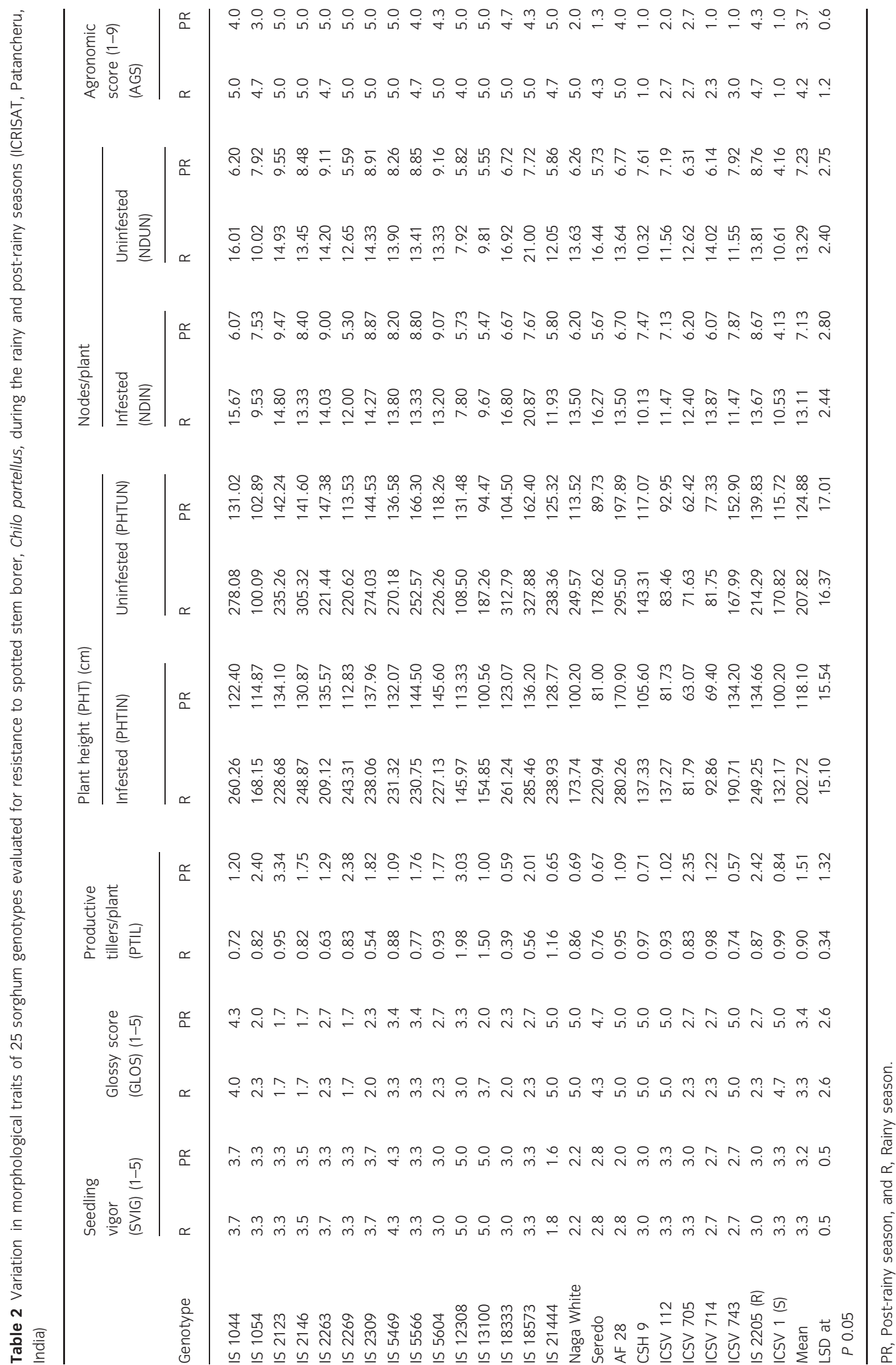


IS 18573 (20.9), whilst the genotypes IS 1044, IS 2123, IS 2263, IS 2309, IS 18333, AF 28 and ICSV 714 had 13.5 - 16.8 nodes/plant. During the postrainy season, significantly fewer nodes $(4.1-6.7)$ were recorded in IS 1044, IS 2269, IS 12308, IS 13100, IS 18333, IS 21444, Naga White, Seredo, AF 28, ICSV 705, ICSV 714 and ICSV 1 as compared to the other genotypes tested. Under uninfested conditions, the number of nodes ranged between 7.9-21.0 and 4.2-9.6 during the rainy and post-rainy seasons, respectively. Stem borer infestation resulted in a significant reduction in number of nodes in IS 1054 (0.5) and IS 1044 (0.3) during the rainy season, and IS 2269 and IS $1054(>0.3)$ during the post-rainy season.

\section{Association of morphological traits with expression of resistance to spotted stem borer, Chilo partellus}

Percentage stem tunnelling showed a significant and positive correlation with percentage plant with deadhearts, exit/entry holes of the C. partellus larvae and numbers of larvae and pupae/plant during the rainy season (Table 3). Amongst the morphological traits, plant height under uninfested conditions was positively associated with seedling vigour and number of internodes during the rainy and post-rainy seasons, whilst leaf glossiness scores were significantly and negatively associated with seedling vigour, plant height under borer-infested conditions and number of internodes under uninfested conditions. Overall resistance scores were positively associated with recovery resistance score and loss in grain yield during the post-rainy season, but not in the rainy season, and negatively associated with agronomic scores, indicating that most of the stem borer-resistant lines had poor agronomic desirability. Loss in grain yield was negatively associated with grain yield under borer-infested conditions. Leaf feeding scores were positively associated with overall resistance scores, but negatively associated with the agronomic scores, whilst percentage plants with deadhearts were positively associated with plant height under borer infestation and overall resistance scores, and

Table 3 Correlation between stem borer resistance parameters, agronomic traits, selection scores and indices, and grain yield in 25 genotypes of sorghum under artificial infestation with stem borer, Chilo partellus (ICRISAT, Patancheru, India) (below diagonal - rainy season and above diagonal - post-rainy season)

\begin{tabular}{|c|c|c|c|c|c|c|c|c|c|c|c|c|c|c|c|c|}
\hline \multirow[b]{2}{*}{ Trait } & \multicolumn{5}{|c|}{ Stem borer damage parameters } & \multicolumn{5}{|c|}{ Agronomic traits } & \multicolumn{3}{|c|}{ Selection scores } & \multicolumn{3}{|c|}{ Grain yield } \\
\hline & LFS & $\mathrm{DH}$ & $\mathrm{EH}$ & TN & LP & SVIG & GLOS & PTIL & PHTUN & NDUN & ORS & REC & AGS & GYIN & GYUN & GYLOS \\
\hline \multicolumn{17}{|l|}{$\begin{array}{l}\text { Post-rainy } \\
\text { season }\end{array}$} \\
\hline LFS & & 0.04 & -0.13 & -0.35 & -0.05 & 0.00 & 0.12 & -0.24 & -0.08 & 0.14 & 0.33 & $0.64 * *$ & -0.13 & -0.21 & 0.01 & 0.32 \\
\hline $\mathrm{DH}$ & 0.17 & & -0.19 & 0.24 & 0.18 & $-0.52^{\star \star}$ & $0.54 * *$ & -0.36 & -0.15 & -0.23 & $0.54 * \star$ & 0.27 & $-0.69 * \star$ & 0.18 & 0.30 & 0.04 \\
\hline $\mathrm{EH}$ & -0.22 & 0.06 & & 0.13 & 0.37 & 0.23 & -0.27 & 0.31 & 0.09 & 0.04 & -0.12 & 0.02 & 0.07 & -0.06 & -0.15 & -0.11 \\
\hline TN & 0.18 & $0.55^{\star *}$ & $0.55^{\star \star}$ & & 0.01 & 0.23 & 0.12 & 0.34 & -0.20 & -0.15 & 0.21 & -0.12 & -0.14 & 0.03 & 0.04 & 0.00 \\
\hline LP & -0.15 & 0.37 & 0.35 & $0.50 * \star$ & & 0.03 & 0.05 & -0.13 & -0.29 & -0.07 & 0.02 & -0.01 & -0.38 & -0.02 & -0.06 & -0.15 \\
\hline SVIG & -0.11 & 0.04 & $0.55^{\star \star}$ & 0.28 & 0.12 & & -0.44 & 0.37 & -0.08 & 0.02 & -0.39 & -0.22 & 0.35 & -0.23 & -0.44 & -0.13 \\
\hline GLOS & 0.32 & $0.46^{\star}$ & -0.13 & 0.36 & 0.30 & -0.30 & & $-0.65^{\star *}$ & 0.10 & -0.38 & $0.59 * \star$ & 0.05 & $-0.65^{\star \star}$ & 0.39 & $0.58^{\star \star}$ & 0.07 \\
\hline PTIL & 0.03 & $0.53^{* *}$ & 0.34 & $0.52^{\star \star}$ & 0.29 & 0.45 & 0.22 & & 0.10 & 0.35 & -0.36 & -0.06 & $0.46^{*}$ & -0.31 & -0.39 & -0.06 \\
\hline PHTUN & -0.24 & $-0.54 \star \star$ & 0.10 & $-0.44^{\star}$ & -0.09 & -0.08 & -0.16 & $-0.44^{\star}$ & & $0.46^{*}$ & 0.04 & 0.01 & 0.35 & 0.11 & 0.03 & -0.17 \\
\hline NDUN & -0.16 & $-0.65^{\star *}$ & -0.05 & $-0.44^{\star}$ & -0.01 & -0.27 & -0.29 & $-0.70^{* *}$ & $0.63^{\star \star}$ & & -0.24 & 0.20 & 0.33 & -0.03 & -0.09 & -0.10 \\
\hline ORS & 0.50 & $0.40^{\star}$ & -0.35 & 0.24 & -0.04 & -0.37 & $0.56^{* *}$ & -0.03 & $-0.54^{* *}$ & -0.22 & & $0.55^{\star *}$ & $-0.48^{*}$ & -0.30 & 0.13 & $0.48^{*}$ \\
\hline REC & -0.39 & -0.30 & 0.11 & -0.01 & 0.21 & 0.25 & -0.24 & 0.36 & 0.24 & 0.27 & -0.17 & & -0.29 & -0.36 & -0.06 & 0.39 \\
\hline AGS & $-0.40^{*}$ & -0.37 & 0.25 & -0.39 & 0.08 & 0.14 & -0.43 & -0.16 & $0.69^{* *}$ & $0.43^{*}$ & $-0.81^{\star \star}$ & 0.19 & & -0.24 & $-0.48^{\star}$ & -0.21 \\
\hline GYIN & 0.15 & -0.11 & $-0.48^{\star}$ & -0.39 & -0.23 & -0.39 & -0.10 & $-0.48^{*}$ & -0.07 & 0.11 & 0.24 & 0.00 & -0.24 & & $0.73^{\star \star}$ & -0.47 \\
\hline GYUN & 0.21 & 0.11 & -0.35 & -0.16 & -0.25 & -0.31 & 0.14 & -0.38 & -0.26 & -0.05 & $0.42^{\star}$ & -0.09 & $-0.45^{\star}$ & $0.80^{* *}$ & & 0.22 \\
\hline GYLOS & 0.06 & 0.30 & 0.19 & 0.35 & 0.02 & 0.20 & 0.23 & 0.12 & -0.34 & -0.19 & 0.25 & -0.10 & -0.37 & -0.18 & 0.39 & \\
\hline & \multicolumn{16}{|c|}{ Rainy season } \\
\hline
\end{tabular}

Stem borer damage parameters (LFS, leaf feeding score; DH, deadhearts; EH, stem borer entry/exit holes; TN, stem tunneling; and LP, numbers of larvae/pupae per plant). Agronomic traits (SVIG, Seedling vigor; GLOS, Leaf glossiness score; PTIL, number of productive tillers; PHTUN, plant height under uninfested conditions; and NDUN, number of internodes under uninfested conditions). Selection scores (ORS, overall resistance score; REC, recovery resistance score; and AGS, agronomic score). Grain yield (GYIN, grain yield under borer infested conditions; GYUN, grain yield under uninfested conditions; and GYLO, grain yield loss due to stem borer damage).

$*, * *$ Correlation coefficients significant at $\mathrm{P} \leq 0.05$, and 0.01 , respectively. 
negatively associated with agronomic scores, and plant height and number of internodes under uninfested conditions during the rainy season. Glossy scores were positively associated with percentage plants with deadhearts in both the seasons, whilst seedling vigour was negatively associated with deadhearts in the post-rainy season. Exit/entry holes of the borer larvae in the stem were positively associated with seedling vigour, but negatively associated with grain yield under borer-infested conditions. Percentage stem tunnelling was positively associated with plant height under infested conditions, but negatively with plant height and number of internodes under uninfested conditions, and agronomic scores and grain yield. Differences in degree and nature of association between different damage parameters, morphological traits and grain yield during the rainy and post-rainy seasons were largely because of differences in plant growth rates owing to photoperiod sensitivity of different genotypes.

In view of complex interactions between different damage parameters and their influence on grain yield, loss in grain yield was considered as a dependant variable, whilst different damage parameters were regarded as independent variables to compute the direct and indirect effects of different traits on expression of resistance to C. partellus. The parameters considered for this purpose were the ones that were significantly correlated with loss in grain yield in one or both the seasons (Table 4). The damage parameters having an indirect effect on plant height, reduction in photosynthetic efficiency (leaf damage), may also be considered as selection criteria to breed for resistance to stem borer, C. partellus.

Reduction in plant height not only showed significant correlation with grain yield loss $\left(r=0.47^{*}\right)$ but also showed positive direct effects $\left(0.56^{* *}\right)$ on grain yield $\left(*,{ }^{* *}\right.$ correlation coefficients significant at $P$ 0.05 and 0.01 , respectively) (Table 4). Tunnel length did not show any association with loss in grain yield (0.19) but had the highest direct $\left(0.51^{* *}\right)$ effects. In contrast, deadhearts were negatively correlated with grain yield loss $(-0.30)$, but the direct effects on grain yield were positive $(0.33)$. During the postrainy season, direct effects of reduction in plant height, tunnel length and deadhearts were relatively large on grain yield loss. However, the tunnel length had the highest direct effects (0.62) on grain yield loss, followed by tunnelling percentage $(0.24)$, and leaf feeding score (0.24). Exit holes and number of larvae and pupae ( $r=-0.38$ and -0.28 , respectively) exhibited negative direct effects on grain yield loss.

The negative association between deadhearts and seedling vigour $\left(-0.52^{* *}\right)$ in the post-rainy season indicated that low temperatures during the seedling stages resulted in stunted growth in borer-susceptible

Table 4 Path coefficients showing direct and indirect effects of various stem borer damage parameters on loss in grain yield under artificial infestation with stem borer, Chilo partellus, during the rainy and post-rainy seasons (ICRISAT, Patancheru, India)

\begin{tabular}{|c|c|c|c|c|c|c|c|c|}
\hline \multirow[b]{2}{*}{$\begin{array}{l}\text { Stem borer } \\
\text { damage } \\
\text { parameters }\end{array}$} & \multicolumn{7}{|c|}{ Indirect effects } & \multirow[b]{2}{*}{$\begin{array}{l}\text { Correlation } \\
\text { with loss in } \\
\text { grain yield }\end{array}$} \\
\hline & $\begin{array}{l}\text { Direct } \\
\text { effects }\end{array}$ & $\begin{array}{l}\text { Leaf } \\
\text { feeding } \\
\text { score }\end{array}$ & $\begin{array}{l}\text { Dead- } \\
\text { hearts }\end{array}$ & $\begin{array}{l}\text { Exit } \\
\text { holes } \\
\text { /plant }\end{array}$ & $\begin{array}{l}\text { Tunnel } \\
\text { length/ } \\
\text { plant }\end{array}$ & $\begin{array}{l}\text { Stem } \\
\text { tunneling } \\
(\%)\end{array}$ & $\begin{array}{l}\text { Larvae } \\
\text { and } \\
\text { pupae/plant }\end{array}$ & \\
\hline \multicolumn{9}{|l|}{ Rainy season } \\
\hline Leaf feeding score & -0.058 & & 0.054 & -0.020 & -0.006 & -0.019 & -0.041 & -0.090 \\
\hline Deadhearts & 0.325 & -0.010 & & 0.005 & 0.142 & -0.133 & -0.077 & 0.252 \\
\hline Exit holes/plant & 0.079 & 0.014 & 0.020 & & 0.346 & -0.133 & -0.072 & 0.254 \\
\hline Tunnel length/plant & 0.512 & 0.001 & 0.090 & 0.054 & & -0.190 & -0.096 & 0.371 \\
\hline Stem tunneling (\%) & -0.240 & -0.005 & 0.180 & 0.044 & 0.405 & & -0.104 & 0.280 \\
\hline $\begin{array}{l}\text { Larvae and } \\
\text { pupae/plant }\end{array}$ & -0.207 & 0.012 & 0.121 & 0.028 & 0.238 & -0.121 & & 0.071 \\
\hline Residual & 0.411 & & & & & & & \\
\hline \multicolumn{9}{|l|}{ Post-rainy season } \\
\hline Leaf feeding score & 0.236 & & 0.004 & 0.050 & 0.048 & -0.083 & 0.014 & 0.269 \\
\hline Deadhearts & 0.112 & 0.009 & & 0.072 & -0.149 & 0.058 & -0.050 & 0.052 \\
\hline Exit holesılplant & -0.384 & -0.031 & -0.021 & & 0.044 & 0.031 & -0.104 & -0.465 \\
\hline Tunnel lengthiplant & 0.617 & 0.018 & -0.027 & -0.271 & & -0.030 & -0.118 & 0.189 \\
\hline Stem tunneling (\%) & 0.238 & -0.082 & 0.027 & -0.050 & -0.076 & & -0.003 & 0.054 \\
\hline $\begin{array}{l}\text { Larvae and } \\
\text { pupaelplant }\end{array}$ & -0.283 & -0.012 & 0.020 & -0.140 & 0.257 & 0.003 & & -0.155 \\
\hline Residual & 0.536 & & & & & & & \\
\hline
\end{tabular}


genotypes. Leaf glossiness score was significantly and positively correlated with deadhearts in the rainy $\left(0.46^{*}\right)$ and the post-rainy $\left(0.54^{*}\right)$ seasons. Negative association between deadhearts and plant height $\left(-0.58^{* *}\right)$ and number of nodes/plant $\left(-0.65^{* *}\right)$ indicated that dwarf genotypes with fewer nodes suffered greater deadheart formation owing to stem borer damage. Late flowering genotypes were prone to high deadheart formation as compared to early flowering ones. This may be due to either prolonged duration of plant whorl stage or delayed panicle initiation, extending the vulnerable period to borer attack. Similarly, the negative and significant correlation between the number of nodes/plant and stem tunnelling $(-0.42 *)$ indicated that the larvae spent more time in entering and exiting plants with more number of internodes as compared to plants with fewer internodes.

Genetic variation in different components of resistance to spotted stem borer, Chilo partellus

Genetic variability is one of the most important prerequisite for efficient selection and breeding for resistance to C. partellus. Loss in grain yield and deadheart percentages revealed ample genetic variability for resistance to C. partellus. The values for PCV were slightly higher than the GCV for all the stem borer-resistant parameters (Table 5). The PCV values were moderate for exit holes, productive tillers/plant, tunnel length and percentage tunnelling/ plant in both the seasons. The GCV values were high for productive tillers/plant, exit holes, tunnel length and per cent tunnelling/plant in the rainy season. Heritability in broad sense $\left(\mathrm{h}^{2}\right)$ ranged from 0.19 (tunnel length/plant) to 0.69 (productive tillers/ plant). The heritability estimates were rather low to moderate for leaf feeding damage (0.42 and 0.45), and deadhearts $(0.50$ and 0.58$)$ in rainy and the post-rainy seasons, respectively. The productive tillers/plant (0.69), exit holes/plant (0.51) in the rainy season and larvae and pupae/plant (0.82) in the post-rainy season also showed high heritability. The expected genetic gain ranged $6.47-49.63 \%$ for various traits in the rainy season and $8.71-58.35 \%$ in the post-rainy season. Highest heritability estimate was obtained for productive tillers/plant in the rainy season, and larvae and pupae/plant in the post-rainy

Table 5 Estimates of variability and genetic parameters for stem borer, Chilo partellus, resistance in 25 genotypes of sorghum during the rainy and post-rainy seasons (ICRISAT, Patancheru, India)

\begin{tabular}{|c|c|c|c|c|c|c|c|c|}
\hline $\begin{array}{l}\text { Estimate of } \\
\text { genetic } \\
\text { variability }\end{array}$ & Season & $\begin{array}{l}\text { Leaf } \\
\text { feeding } \\
\text { score }\end{array}$ & $\begin{array}{l}\text { Deadhearts } \\
(\%)\end{array}$ & $\begin{array}{l}\text { Productive } \\
\text { tillers/plant }\end{array}$ & $\begin{array}{l}\text { Exit } \\
\text { holes/ } \\
\text { plant }\end{array}$ & $\begin{array}{l}\text { Tunnel } \\
\text { length/ } \\
\text { plant }\end{array}$ & $\begin{array}{l}\text { Tunneling } \\
\text { (\%) }\end{array}$ & $\begin{array}{l}\text { Larvae } \\
\text { and } \\
\text { pupae/plant }\end{array}$ \\
\hline \multirow[t]{2}{*}{ Mean } & Rainy & 5.80 & 54.20 & 2.40 & 2.40 & 11.0 & 13.10 & 0.90 \\
\hline & Post-rainy & 5.80 & 14.10 & 1.00 & 1.00 & 3.40 & 28.80 & 0.70 \\
\hline \multicolumn{9}{|l|}{$\begin{array}{c}\text { Components } \\
\text { of variance }\end{array}$} \\
\hline \multirow[t]{2}{*}{$\sigma^{2} p$} & Rainy & 0.05 & 102.96 & 0.10 & 1.03 & 15.80 & 11.84 & 0.01 \\
\hline & Post-rainy & 0.05 & 47.28 & 0.64 & 0.38 & 3.74 & 10.78 & 0.00 \\
\hline \multirow[t]{2}{*}{$\sigma^{2} g$} & Rainy & 0.03 & 52.33 & 0.07 & 0.53 & 2.94 & 4.42 & 0.00 \\
\hline & Post-rainy & 0.02 & 27.42 & 0.19 & 0.04 & 0.88 & 0.92 & 0.00 \\
\hline \multirow[t]{2}{*}{$\sigma^{2} c$} & Rainy & 0.02 & 50.63 & 0.03 & 0.50 & 12.86 & 7.42 & 0.01 \\
\hline & Post-rainy & 0.03 & 19.86 & 0.45 & 0.34 & 2.86 & 9.86 & 0.00 \\
\hline \multicolumn{9}{|l|}{$\begin{array}{c}\text { Coefficient of } \\
\text { variance (\%) }\end{array}$} \\
\hline \multirow[t]{2}{*}{ PCV } & Rainy & 8.69 & 18.72 & 34.79 & 42.63 & 36.30 & 26.37 & 12.52 \\
\hline & Post-rainy & 9.35 & 48.84 & 52.96 & 64.64 & 57.33 & 64.57 & 30.33 \\
\hline \multirow{2}{*}{$\begin{array}{l}\text { Genotypic } \\
\text { coefficients of } \\
\text { variation }\end{array}$} & Rainy & 5.61 & 13.34 & 28.95 & 30.50 & 16.66 & 16.12 & 6.27 \\
\hline & Post-rainy & 6.29 & 37.19 & 28.78 & 20.35 & 27.83 & 29.66 & 27.51 \\
\hline \multirow{2}{*}{$\begin{array}{l}\text { Broad-sense } \\
\text { heritability } \\
(\%)\left(h^{2}\right)\end{array}$} & Rainy & 42.0 & 50.00 & 69.00 & 51.00 & 19.00 & 38.00 & 25.00 \\
\hline & Post-rainy & 45.0 & 58.00 & 30.00 & 11.00 & 24.00 & 21.00 & 82.00 \\
\hline \multirow[t]{2}{*}{ Genetic advance (\%) } & Rainy & 0.19 & 10.62 & 0.44 & 1.07 & 1.58 & 2.65 & 0.06 \\
\hline & Post-rainy & 0.20 & 8.22 & 0.49 & 0.13 & 0.94 & 3.59 & 63.70 \\
\hline \multirow{2}{*}{$\begin{array}{l}\text { Genetic gain } \\
\text { (\% of mean) }\end{array}$} & Rainy & 7.45 & 19.60 & 49.63 & 44.95 & 13.94 & 20.29 & 6.47 \\
\hline & Post-rainy & 8.71 & 58.35 & 32.21 & 13.61 & 27.53 & 28.07 & 51.39 \\
\hline
\end{tabular}


season. The PCV values were slightly higher than GCV values for the grain yield under uninfested conditions but were low to moderate for loss in grain yield. The GCV values also showed a similar trend. Heritability estimates for grain yield under uninfested conditions and loss in grain yield were $82-$ 87 and $78-83 \%$, respectively, in the rainy and post-rainy seasons. Expected genetic gain was high for grain yield and loss in grain yield under borer infestation in both the seasons. High estimates for grain yield and loss in grain yield is a reflection of greater genetic variability for these traits.

\section{Multi-trait $D^{2}$ cluster analysis}

In view of continuous damage by C. partellus at different phonological growth stages of the sorghum plant, cluster analysis was employed for multi-trait selection, focusing on interrelationships amongst the resistance variables and grain yield under borer infestation, and assigns genotypes into discrete classes. This technique also enabled observations to be sorted into groups, so that the degree of association of Euclidean distances is high amongst members of the same group and low between genotypes of different groups. Analysis of the genetic interrelationships provided a relative measure of borer resistance and the genetic distances within the genotypes as a measure of the average genetic divergence for resistance to C. partellus. This procedure was used for grouping of sorghum genotypes based on six stem borer damage variables (leaf feeding, deadhearts, tunnel length, tunnelling percentage, plant height reduction and productive tillers), grain yield under borer-infested and uninfested conditions, and loss in grain yield as a result of borer damage.

The $D^{2}$ statistic using stem borer damage variables and grain yield resulted in four and five clusters for germplasm accessions in rainy and post-rainy seasons, respectively (Tables 6 and 7). The Euclidean intra-cluster distances ranged from 0.00 to 1.20 in the rainy season and 0.54 to 2.05 in the post-rainy season. The order of intra-cluster distances was III $>$ II $>$ I $>$ IV and V > III > I > II > IV in the rainy and post-rainy seasons, respectively. The inter-cluster values were maximum between the clusters III and IV, and I and V in the rainy and post-rainy seasons, respectively.

\section{Discussion}

There was considerable genetic variability amongst the sorghum genotypes for different types of damage
Table 6 Average Euclidean intra-cluster (in bold) and inter-cluster distances based on stem borer damage parameters and grain yield during the rainy and post-rainy seasons (ICRISAT, Patancheru, India)

\begin{tabular}{|c|c|c|c|c|c|}
\hline \multirow[b]{2}{*}{ Cluster } & \multicolumn{5}{|c|}{ Cluster } \\
\hline & 1 & $\|$ & III & IV & v \\
\hline \multicolumn{6}{|l|}{ Rainy } \\
\hline \multicolumn{6}{|l|}{ season } \\
\hline I & 0.25 & 0.43 & 0.62 & 0.19 & \\
\hline ॥ & & 0.32 & 0.67 & 1.88 & \\
\hline III & & & 0.60 & 2.64 & \\
\hline IV & & & & 0.00 & \\
\hline \multicolumn{6}{|c|}{ Post-rainy } \\
\hline \multicolumn{6}{|c|}{ season } \\
\hline I & 0.61 & 0.72 & 0.96 & 0.71 & 1.15 \\
\hline$\|$ & & 0.41 & 0.74 & 0.55 & 0.89 \\
\hline III & & & 0.65 & 0.63 & 1.13 \\
\hline IV & & & & 0.27 & 0.74 \\
\hline V & & & & & 1.02 \\
\hline
\end{tabular}

Table 7 Grouping of sorghum genotypes based on stem borer damage and grain yield of 25 sorghum genotypes during the rainy and post-rainy seasons (ICRISAT, Patancheru, India)

\begin{tabular}{|c|c|c|}
\hline Season & $\begin{array}{l}\text { No of } \\
\text { genotypes }\end{array}$ & Genotype \\
\hline \multicolumn{3}{|l|}{ Rainy } \\
\hline 1 & 10 & $\begin{array}{l}\text { IS } 1044 \text {, IS } 18573 \text {, } \\
\text { AF } 28 \text {, IS } 2123 \text {, IS } 5469 \text {, } \\
\text { IS } 2269 \text {, IS } 2263 \text {, IS } 2146 \text {, } \\
\text { IS } 18333 \text {, and IS } 2309\end{array}$ \\
\hline$\|$ & 9 & $\begin{array}{l}\text { IS } 1054 \text {, ICSV } 112 \text {, IS } 12308 \text {, } \\
\text { IS 5566, IS 5604, IS 2205, } \\
\text { Seredo, IS 21444, and I } \\
\text { CSV } 743\end{array}$ \\
\hline III & 5 & $\begin{array}{l}\text { IS } 13100 \text {, ICSV 705, ICSV } 112 \text {, } \\
\text { CSH 9, and Naga White }\end{array}$ \\
\hline IV & 1 & ICSV 714 \\
\hline \multicolumn{3}{|c|}{ Post-rainy } \\
\hline 1 & 4 & $\begin{array}{l}\text { IS } 1044 \text {, Naga White, IS } 12308 \text {, } \\
\text { and IS } 13100\end{array}$ \\
\hline$\|$ & 6 & $\begin{array}{l}\text { IS } 21444 \text {, ICSV 705, ICSV 112, } \\
\text { CSH 9, Seredo, and AF } 28\end{array}$ \\
\hline III & 4 & $\begin{array}{l}\text { ICSV } 743 \text {, ICSV 112, IS } 18573 \text {, } \\
\text { and ICSV } 714\end{array}$ \\
\hline IV & 8 & $\begin{array}{l}\text { IS } 2123 \text {, IS } 2146 \text {, IS } 2263 \text {, } \\
\text { IS } 5469 \text {, IS } 2309 \text {, IS } 2205 \text {, } \\
\text { IS } 2269 \text {, and IS } 5566\end{array}$ \\
\hline $\mathrm{V}$ & 3 & IS 5604, IS 18333, and IS 1054 \\
\hline
\end{tabular}

caused by C.partellus. The leaf feeding score was consistently low in case of IS 5469, IS 5604 and ICSV 714, suggesting that low larval establishment in the whorl leaves (Davis 1985) and antibiosis are the major components of resistance to C. partellus in 
these genotypes. Low leaf feeding and low larval establishment are important components of resistance to C.partellus in sorghum (Chapman et al. 1983; Bernays et al. 1983; Taneja and Woodhead 1989; Saxena 1990; van den Berg and Westhuizen 1998). The resistance in IS 1044 and IS 2146 has earlier been reported to be because of antixenosis and antibiosis (Singh et al. 1983; Singh and Rana 1984). Greater levels of antibiosis in IS 18573 were reflected in terms of reduced leaf feeding and low deadheart incidence, whilst IS 2263 showed both antibiosis and tolerance. Leaf feeding incidence is strongly associated with loss in grain yield in sorghum (Ampofo 1986) and maize by C.partellus (Singh and Sajjan 1982) and to European corn borer, O. nubilalis (Everett et al. 1958). However, Starks and Doggett (1970) suggested that leaf feeding by C. partellus in sorghum is a poor indicator of expected grain yield as production of newer leaves may compensate the leaf damage. Loss in photosynthetic leaf area causes reduction in leaf size and results in reduced plant vigour. Another component contributing stem borer resistance is the phenotypic plasticity or tolerance, which allows the plants to produce axillary tillers, which also contributed to grain yield.

Deadheart formation is a consequence of damage to the apical meristem after successful establishment of larvae on young sorghum plants and leads to losses in plant stand. Low deadheart formation was recorded in IS 1044, IS 2146, IS 2309, IS 5469, IS 5604, IS 18333 and IS 2205 in both the seasons. Several workers have used deadhearts as a criterion to select for stem borer resistance (Taneja and Leuschner 1985; Singh and Rana 1989) and as an indicator of loss in grain yield in sorghum (Alghali 1987) and maize (Mohyuddin and Attique 1978). Fewer exit holes in IS 1054 and AF 28 indicated the existence of antibiosis against the larvae. Low pupation has also been suggested as a selection criterion for resistance to C. partellus (Singh et al. 1983; Singh and Rana 1984; van den Berg and Westhuizen 1998). Significantly low tunnelling in IS 1054, IS 2123 , IS 2146 and IS 21444 suggested that the larvae either took more time to enter inside the stems of these genotypes or fewer larvae survived on these genotypes. Extent of stem tunnelling is influenced by antibiosis and has been used to measure genotypic susceptibility to C. partellus (Alghali 1987). Ajala et al. $(1993,1995)$ suggested that stem tunnelling rather than leaf feeding damage is the most important factor for estimating tolerance, but the effect of leaf feeding and deadhearts cannot be ignored. Although internode boring and tunnel length gave similar estimates of damage, the relationship between stem tunnelling and grain yield was quite variable (MacFarlane 1990).

Recovery of larvae and pupae at harvest has been used as an index of larval survival/establishment, which is directly related to tunnel length. In spite of severe leaf injury and stem tunnelling, the plants bearing normal panicles with significantly low loss in grain yield have been identified in the sorghum (Jotwani 1978; Dabrowski and Kidiavai 1983). Deadheart formation in the main plant results in the formation of axial tillers, which at times contribute to compensation in grain yield (van Rensburg and van den Berg 1992; Bardner and Fletcher 1974). However, the grain yield under stem borer infestation depends only on production of axial tillers, but also on synchronous maturity with the main plants. More productive tillers were observed in IS 2123, IS 12308, IS 13100 and ICSV 714. Compensation in grain yield by the productive tillers masks the actual loss in grain yield (van Rensburg and van den Berg 1992). However, induction of tiller formation and their ability to produce grain depend on time of infestation, insect pressure and availability of moisture and nutrients in the soil. As a result, this component of resistance is not stable across seasons and locations. In addition, axial tillers often mature 2025 later than the main plant and, as a result, suffer greater damage by sorghum midge, Stenodiplosis sorghicola (Coq.), and head bug, Calocoris angustatus (Leth.) (Sharma 1993). Path coefficient analysis indicated that deadheart formation and reduction in plant height in the rainy season had positive direct effects on grain yield. Highly negative indirect effects of deadhearts for grain yield loss in the rainy season may be due to a greater number of non-productive tillers and reduction in plant vigour/height. Negative and significant correlation between plant height and deadhearts with grain yield loss is in conformity with the earlier reports in sorghum (Mohyuddin and Attique 1978) and maize (Ajala 1994).

In view of significant and positive correlation between exit holes and tunnelling percentage, the exit holes have been considered as an indicator of stem tunnelling in sorghum (Singh et al. 1983; van Rensburg and van den Berg 1992) and sugarcane (Bessin et al. 1990). There was a negative association between tunnel length and days to $50 \%$ flowering. Similar observations have been reported in maize for damage by C.partellus (Ajala 1994) and O. nubilalis in corn (Russell et al. 1974; Melchinger et al. 1998). The genotypes having high grain yield under stem 
borer infestation and low loss in grain yield were considered resistant (ICSV 714, IS 2123 and IS 2205). Although not significant, the negative association between grain yield and yield loss indicated that high-yielding genotypes showed greater ability to compensate for loss in grain yield owing to C. partellus damage. Similar results have earlier been reported in corn for damage by O. nubilalis (Lynch 1980), Southwestern corn borer (Diatraea grandiosella Dyar) (Klenke et al. 1986a,b; Thome et al. 1994; Anglade et al. 1996) and pink borer (Sesamia nonagrioides Lefebvre) (Butron et al. 1998, 1999). The genotypes IS 1044, IS 1054 and IS 18573 showed resistance to leaf feeding, deadhearts and stem tunnelling; IS 5469 for leaf feeding and deadhearts and ICSV 714 for leaf feeding and stem tunnelling. ICSV 714 exhibited resistance to leaf feeding, whilst IS 1044, IS 2146, IS 2205, IS 2309, IS 5469, IS 18333 and IS 18573 were resistant to deadheart formation. Stem borer infestation caused a significant grain yield reduction in ICSV 743, but not in the resistant check, IS 2205. Compensation in grain yield loss contributed to overall resistance in IS 2123, IS 2146 and IS 18333 in the rainy season and IS 5469, IS 5604 and IS 18573 in the post-rainy season.

The overall resistance scores provided an estimate of overall performance of a genotype for the expression of resistance to stem borer damage, whereas the recovery score (expressed in terms of productive tillers) reflected the genotypic response to borer damage and ability to compensate for loss in grain yield. The agronomic score indicated the productive potential of a genotype under borer infestation. The broad-sense heritability estimates were high for leaf feeding, deadhearts, productive tillers, exit holes and stem tunnelling, indicating that selection for these parameters may be effective to screen and breed for resistance to stem borer. The estimates for GCV ranged from 5.6130.50 to $6.29-37.19$ during the rainy and post-rainy seasons, respectively. In view of low estimates of genetic advance for leaf feeding, deadhearts and number of larvae and pupae, improvement for these parameters through selection may be slow. However, the magnitude of GCV considered in conjunction with heritability estimates indicated that larger gains could be made by the selection of genotypes based on deadhearts and number of exit holes. Heritability estimates were lower during the post-rainy season compared with the rainy season. Moderate estimates of heritability and expected genetic advance were observed for leaf feeding and deadhearts in both the seasons. Grain yield and loss in grain yield also showed a similar trend, suggesting that selection of genotypes based on grain yield per se would also be quite effective, and that selection should be made under borer infestation. Rana et al. (1984) reported that heritability estimates for exit holes were higher than for stem borer tunnelling and larvae and pupae recovered at harvest, whilst Pathak (1985) reported low heritability estimates for stem tunnelling in different cross combinations.

Further, selection for grain yield under stem borer infestation may result in improved resistance/tolerance in certain genotypes. However, when a high level of resistance is sought, it is usually associated with undesirable agronomic traits. Thus, it would be desirable to increase the level of tolerance in highyielding genotypes and make use of this as a selection criterion. Grain yield showed high broad-sense heritability estimate, and genetic advance based on heritability estimates also supported this assumption. The fact that heritability estimates for grain yield were usually higher than other stem borer resistance parameters, suggested that stem borer effects on grain yield constituted a major proportion of total phenotypic variation for this trait. In view of complexity of interactions between C.partellus and its host plant, cluster analysis can be used for assessing the diversity in stem borer-resistant lines in sorghum by measuring multiple parameters and classifying the sorghum genotypes into different groups. Multitrait analysis resulted in four and five clusters of germplasm accessions in the rainy and post-rainy seasons, respectively. Multi-trait clustering has also been reported to be useful to select genotypes for resistance to Maruca vitrata (Geyer) in cowpea (Oghiake and Odulaja 1993) and Diatraea saccharalis in sugarcane (White 1993). The genotypes placed in different groups based on cluster analysis, and showing resistance to leaf feeding, deadheart formation, stem tunnelling and/or compensation in grain yield can be selected for use in sorghum improvement.

\section{Acknowledgements}

We thank Messrs. K.V. Hari Prasad, G. Pampapathy, V. Venkateswara Rao, S.V.N. Chandra, J. Raja Rao, Mrs. Ponnamma and Mrs. Vimala for their help.

\section{References}

Ajala SO, 1994. Maize (Zea mays L.) and stem borer (Chilo partellus Swinhoe) infestation/damage and plant resistance. Maydica 39, 203-205.

Ajala SO, Odulaja A, Saxena KN, 1993. Assessing tolerance to stem borer attack in maize: basic considerations and views. In: Beneficial African Insects: A Renewable 
Natural Resource, pp. 71-74. 10th Meeting and Scientific Conference of African Associate Insects, 5-10 Sept 1993, Mombasa, Kenya.

Ajala SO, Saxena KN, Chiliswa P, 1995. Selection in maize (Zea mays L.) for resistance to the spotted stem borer (Chilo partellus (Swinhoe)). Maydica 40, 137-140.

Alghali AM, 1987. Effect of time of Chilo partellus Swinhoe (Lepidoptera: Pyralidae) infestation on yield loss and compensatory ability in sorghum cultivars. Trop. Agric. (Trinidad) 64, 144-148.

Ampofo JKO, 1986. Maize stalk borer (Lepidoptera: Pyralidae) damage and plant resistance. Environ. Entomol. 15, 1124-1129.

Anglade P, Gouesnard B, Boyat A, Panouille A, 1996. Effects of multitrait recurrent selection for European corn borer tolerance and for agronomic traits in FS 12 maize synthetic. Maydica 41, 97-104.

Bardner R, Fletcher KE, 1974. Insect infestation and their effects on the growth and yield of field crops: a review. Bull. Ent. Res. 64, 141-179.

van den Berg J, Westhuizen MC, 1998. The effect of resistant sorghum hybrids in suppression of Busseola fusca Fuller and Chilo partellus (Swinhoe) populations. Insect Sci. Appl. 18, 31-36.

van den Berg J, van Rensburg JB, Pringle KL, 1990. Damage caused by Chilo partellus (Swinhoe) (Lepidoptera: Pyralidae) to various cultivars of grain sorghum, Sorghum bicolor. L.). Moench Sth. Afr. J. Plant Soil 7, 192-196.

Bernays EA, Chapman RF, Woodhead S, 1983. Behaviour of newly hatched larvae of Chilo partellus (Swinhoe) (Lepidoptera: Pyralidae) associated with their establishment in the host plant, sorghum. Bull. Ent. Res. 73, 75-83.

Bessin RT, Reagan TE, Martin TA, 1990. A moth production index for evaluating sugarcane cultivars for resistance to the sugarcane borer (Lepidoptera: Pyralidae). J. Econ. Entomol. 83, 221-225.

Burton GW, 1951. Quantitative inheritance in pearl millet, Pennisetum glaucum. Agron. J. 43, 409-417.

Butron A, Malvar RA, Velasco P, Revilla P, Ordas A, 1998. Defense mechanisms of maize against pink stem borer. Crop Sci. 38, 1159-1163.

Butron A, Malvar RA, Velasco P, Revilla P, Ordas A, 1999. Combining abilities for maize stem antibiosis. Yield loss, and yield under infestation and noninfestation with pink stem borer. Crop Sci. 39, 691-696.

Chapman RF, Woodhead S, Bernays EA, 1983. Survival and dispersal of young larvae of Chilo partellus (Swinhoe) (Lepidoptera: Pyralidae) in two cultivars of sorghum. Bull. Ent. Res. 73, 65-74.

Dabrowski ZT, Kidiavai EL, 1983. Resistance of some sorghum lines to the spotted stalk borer, Chilo partellus, under western Kenya conditions. Insect Sci. Appl. 4, 119-126.
Davis FM, 1985. Entomological techniques and methodologies used in research programs on plant resistance to insects. Insect Sci. Appl. 6, 391-400.

Everett TR, Chiang HC, Hibbs ET, 1958. Some Factors Influencing Populations of European Corn Borer, Pyrausta Nubilalis (Hubner), in the North Central States. Resistance of Corn, Time of Planting, and Weather Conditions. Minnesota Agriculture Experiment Station, Research Bulletin No. 229, St Paul, Minnesota, USA.

Frey KJ, Horner T, 1955. Comparison of actual and predicted gains in barley selection experiments. Agron. J. 47, 186-188.

Guthrie WD, Dicke FF, Neiswander CR, 1960. Leaf and Sheath Feeding Resistance to the European Corn Borer in Eight Inbred Lines of Dent Corn. Ohio Agriculture Research Station, Research Bulletin No. 860, Columbus, Ohio.

Hallauer AR, Miranda JB, 1981. Quantitative Genetics in Maize Breeding. Iowa State University Press, Ames, Iowa, USA.

Harris KM, 1962. Lepidopterous stem borers of cereals in Nigeria. Bull. Ent. Res. 53, 139-171.

Harris KM, 1985. Lepidopterous stem borers of sorghum. In: Proceedings, International Sorghum Entomology Workshop, July 15-21, 1984, Texas A\&M University, College Station, Texas, USA, pp. 161-168. International Crops Research Institute for the Semi-Arid Tropics (ICRISAT), Patancheru, Andhra Pradesh 502 324, India.

Harris KM, 1990. Bioecology of Chilo species. Insect Sci. Appl. 11, 467-477.

Heinrich GM, Francis CA, Eastin JD, 1983. Stability of grain sorghum yield components across diverse environments. Crop Sci. 23, 209-212.

ICRISAT (International Crops Research Institute for the Semi-Arid Tropics), 1992. Medium Term Plan 1992. International Crops Research Institute for the SemiArid Tropics (ICRISAT), Patancheru, Andhra Pradesh, India.

Johnson HW, Robinson HF, Comstock RE, 1955. Estimates of genetic and environmental variability in soybeans. Agron. J. 47, 314-318.

Jotwani MG, 1978. Investigations on Insect Pests of Sorghum and Millets with Special Reference to Host Plant Resistance. Final Technical Report (1972-1977). Research Bulletin No. 2. Indian Agricultural Research Institute, New Delhi, India, 116 pp.

Jotwani MG, Chaudari S, Singh SP, 1978. Mechanism of resistance to Chilo partellus (Swinhoe) in sorghum. Indian J. Ent. 40, 273-276.

Klenke JR, Russell WA, Guthrie WD, 1986a. Recurrent selection for resistance to European corn borer in a corn synthetic and correlated effects on agronomic traits. Crop Sci. 26, 864-868. 
Klenke JR, Russell WA, Guthrie WD, 1986b. Grain yield reduction caused by second-generation European corn borer in 'BS 9' corn synthetic. Crop Sci. 26, 859-863.

Lynch RE, 1980. European corn borer: yield losses and damage resulting from a simulated natural infestation. J. Econ. Entomol. 73, 141-144.

MacFarlane JH, 1990. Damage assessment and yield losses in sorghum due to the stem borer, Busseola fusca (Fuller) (Lepidoptera: Noctuidae) in northern Nigeria. Trop. Pest Manag. 36, 131-137.

Mahalanobis PC, 1928. A statistical study at Chinese head measurement. J. Asiatic Soc. Bengal 25, 301377.

Maiti RK, Prasada Rao KE, Raju PS, Bidinger FR, 1978. Evaluation of visual scoring for seedling vigor in sorghum. Seed Sci. Technol. 9, 613-622.

Maiti RK, Prasada Rao KE, Raju PS, House LR, 1984. The glossy trait in sorghum. Its characteristics and significance in crop improvement. Field Crops Res. 9, 279289.

Melchinger AE, Kreps R, Spath R, Klein D, Schulz B, 1998. Evaluation of early maturing European maize inbreds for resistance to the European corn borer. Euphytica 99, 115-125.

Mohyuddin AL, Attique MR, 1978. An assessment of loss caused by Chilo zonellus to maize in Pakistan. PANS 24, 111-113.

Oghiake S, Odulaja A, 1993. Classification of cowpea cultivars for field resistance to the legume pod borer, Maruca testulalis in Nigeria using cluster analysis. Ann. Appl. Biol. 22, 699-77.

Pathak RS, 1985. Genetic variation of stem borer resistance and tolerance in three sorghum crosses. Insect Sci. Appl. 6, 359-364.

Rana BS, Singh BU, Jaya Mohan Rao V, Reddy BB, Rao NGP, 1984. Inheritance of stem borer resistance in sorghum. Indian J. Gen. Plant Breed. 44, 7-14.

Rao CR, 1952. Advanced Statistical Methods in Biometrical Research. John Willey and Sons, New York, YSA.

Reddy KVS, Walker PT, 1990. A review of the yield losses in graminaceous crops caused by Chilo spp. Insect Sci. Appl. 11, 563-570.

van Rensburg JB, van den Berg J, 1992. Stem borers in grain sorghum. II. Yield loss compensation in relation to borer attack. Sth. Afr. J. Plant Soil 9, 81-86.

Russell WA, Guthrie WD, Grindeland RL, 1974. Breeding for resistance to first and second broods of European corn borer. Crop Sci. 14, 725-727.

Saxena KN, 1990. Mechanisms of resistance/susceptibility of certain sorghum cultivars to the stem borer, Chilo partellus: role of behaviour and development. Entomol. Exp. Appl. 55, 91-99.

Sharma HC, 1993. Host-plant resistance to insects in sorghum and its role in integrated pest management. Crop Prot. 12, 11-34.
Sharma HC, Nwanze KF, 1997. Mechanisms of Resistance to Insects in Sorghum. Information Bulletin No. 45. International Crops Research Institute for the SemiArid Tropics (ICRISAT), Patancheru, Andhra Pradesh, India, 1-51.

Sharma HC, Taneja SL, Leuschner K, Nwanze KF, 1992. Techniques to Screen Sorghums for Resistance to Insect Pests. Information Bulletin No. 32. International Crops Research Institute for the Semi-Arid Tropics (ICRISAT), Patancheru, Andhra Pradesh, India, 46 pp.

Sharma HC, Taneja SL, Kameswara Rao N, Prasada Rao KE, 2003. Evaluation of Sorghum Germplasm for Resistance to Insect Pests. Information Bulletin No. 63. International Crops Research Institute for the SemiArid Tropics, Patancheru, Andhra Pradesh, India, 177 pp.

Sharma HC, Dhillon MK, Pampapathy G, Reddy BVS, 2007. Inheritance of resistance to spotted stem borer, Chilo partellus in sorghum, Sorghum bicolor. Euphytica 156, 117-128.

Singh BU, Rana BS, 1984. Influence of varietal resistance on oviposition and larval development of stalk-borer, Chilo partellus Swin., and its relationship to field resistance in sorghum. Insect Sci. Appl. 5, 287296.

Singh BU, Rana BS, 1989. Varietal resistance in sorghum to spotted stem borer, Chilo partellus (Swinhoe). Insect Sci. Appl. 10, 3-27.

Singh J, Sajjan SS, 1982. Losses in maize yield due to different damage grades (1-9 scale) caused by maize borer, Chilo partellus (Swinhoe). Indian J. Entomol. 44, 41-48.

Singh BU, Rana BS, Reddy BB, Rao NGP, 1983. Host plant resistance to stalk-borer, Chilo partellus Swin., in sorghum. Insect Sci. Appl. 4, 407-414.

Sithole SZ, 1990. Status and control of the stem borer, Chilo partellus Swinhoe (Lepidoptera: Pyralidae) in southern Africa. Insect Sci. Appl. 11, 481-488.

Starks KJ, Doggett H, 1970. Resistance to spotted stem borer in sorghum and maize. J. Econ. Entomol. 63, 1790-1795.

Taneja SL, Leuschner K, 1985. Methods of rearing, infestation, and evaluation for Chilo partellus resistance in sorghum. In: Proceedings of the International Sorghum Entomology Workshop, July 15-21, 1984, College Station, Texas, USA, pp. 175-188. International Crops Research Institute for the Semi-Arid Tropics (ICRISAT), Patancheru, Andhra Pradesh, India.

Taneja SL, Nwanze KF, 1989. Assessment of yield loss of sorghum and pearl millet due to stem borer damage. In: International Workshop on Sorghum Stem borers, 17-20 Nov 1987. International Crops Research Institute for the Semi-Arid Tropics (ICRISAT), Patancheru, Andhra Pradesh, India, 95-104. 
Taneja SL, Woodhead S, 1989: Mechanism of stem borer resistance in sorghum. In: Proceedings, International Workshop on Sorghum Stem borers, Nov 17-20, 1987, Patancheru, Andhra Pradesh, India, pp. 137-143.

International Crops Research Institute for the SemiArid Tropics (ICRISAT), Patancheru, Andhra Pradesh, India.
Thome CR, Smith ME, Mihm JA, 1994. Yield reduction in a maize diallel under infestation with southwestern corn borer. Crop Sci. 34, 1431-1435.

White WH, 1993. Cluster analysis for assessing sugarcane borer resistance in sugarcane line trials. Field Crops Res. 33, 159-168. 